\title{
DNA Polymorphism and Assessment of Genetic Relationships in Walnut Genotypes Based on AFLP and SAMPL Markers
}

\author{
Salih Kafkas ${ }^{1}$ \\ Department of Horticulture, Faculty of Agriculture, University of Cukurova, 01330, Adana-Turkey \\ Hakan Ozkan \\ Department of Field Crops, Faculty of Agriculture, University of Cukurova, 01330, Adana-Turkey \\ Mehmet Sutyemez \\ Department of Horticulture, Faculty of Agriculture, University of Sutcuimam, Kahramanmaras- \\ Turkey
}

\begin{abstract}
AdDITIONAL INDEX wORDS. walnut, Juglans regia, AFLP, SAMPL, fingerprinting, diversity
Abstract. Turkey has more than 4 million walnut trees (Juglans regia L.), most of which are derived from seedlings, and are nongrafted trees. This characteristic leads to a huge opportunity to select superior walnut genotypes from natural populations for cultivation and for breeding programs. Several selection studies have been performed in the last decades and few genotypes were selected. The goal of this study was to characterize and determine genetic relationships among 21 walnut genotypes with potential in walnut production using amplified fragment length polymorphism (AFLP) and selective amplification of microsatellite polymorphic loci (SAMPL) techniques. Eight primer combinations (six for AFLP and two for SAMPL) were applied to 21 walnut genotypes and a total of 230 bands of which $50.4 \%$ of them were polymorphic were obtained. The SAMPL technique was more effective than AFLP in the separation of very closely related genotypes. Genotypes of the pairs 'Maras-18' with 'Maras-46', 'KSU-5' with 'Sutyemez-1', 'Maras-12' with 'Sutyemez-2,' 'Kaman-3' with 'Kaman-4', and 'KSU-11' with 'Maras-10' were the most closely related.
\end{abstract}

The genus Juglans includes 21 species (Manning, 1978). However, J. regia is the only commonly cultivated species in Europe. Turkey, with $125,000 \mathrm{Mt}$ of nuts, is one of the countries of origin of this species, and is the fourth largest walnut producing country in the world (FAO, 2003). In Turkey, $\approx 4$ million walnut trees are in production and most of them are derived from seedlings (i.e., they are nongrafted trees) (Akca, 2003; Sen, 1986). Although this characteristic provides a very good opportunity for the breeders to select the best genotypes for production as well as walnut breeding programs, it has the disadvantage of giving nonuniform nuts that are unsuitable for market.

Until the beginning of 1970s, nongrafted walnut seedlings were used in Turkey for new walnut plantations. The first selection study from natural populations of the Marmara region was done by Olez (1971) and four walnut genotypes ('Yalova-1', 'Yalova-2', 'Yalova-3', and 'Yalova-4') were selected. Afterwards, Celebioglu (1985) selected the genotypes 'Sebin' and 'Bilecik' according to their yield and nut characteristics. All these genotypes, except 'Yalova-2' (because of alternate bearing), are still used to produce grafted walnut plants in the nurseries. After Celebioglu, a few selections from natural populations were performed in different walnut-producing provinces.

The knowledge of the genetic relationships among walnut genotypes and their pomological characteristics will be very useful in walnut cross-breeding programs. Isozymes were used in different studies to characterize walnut species and cultivars, and to detect interspecific hybrids (Aleta et al., 1990, 1993; Arulsekar et al., 1985, 1986; Fornari et al., 2001; Germain et al., 1993; Louskas

Received for publication 9 Oct. 2004. Accepted for publication 22 Dec. 2004. ${ }^{1}$ To whom reprint requests should be addressed. E-mail address: skafkas@mail. cukurova.edu.tr et al., 1984; Malvolti et al., 1993; Solar et al., 1993; Wenheng, 1984). RFLP markers were also used in walnuts to determine presence of apomixis, to establish phylogenetic relationships in the genus Juglans, to assess genetic diversity and to characterize cultivars (Aly et al., 1992; Fjellstrom et al., 1994; Fjellstrom and Parfitt, 1994a, 1994b, 1995). With the development of polymerase chain reaction (PCR), the randomly amplified polymorphic DNA (RAPD) technique has been employed in walnut to find markers linked to hypersensivity to the cherry leafroll virus, to identify interspecific hybrids, to assess genetic relationships among the genotypes, and to construct a genetic linkage map (Malvolti et al., 1997, 2001; Nicese et al., 1998; Woeste et al., 1996a, 1996b). Inter simple sequence repeats (ISSRs), instead, were only used to characterize Californian walnut cultivar germplasm (Potter et al., 2002).

Amplified fragment length polymorphism (AFLP) technique (Vos et al., 1995) was applied to analyze intraspecific diversity in different fruit and nut tree species but it was never used in walnut. This technique reveals significant levels of DNA polymorphism and appears to be most promising for fingerprinting, mapping, and genetic diversity studies. In addition, one of the main advantages of AFLP technique is its high multiplex ratio, which means that a larger number of amplified products are generated in a single reaction (Powell et al., 1996).

Selective amplification of microsatellite polymorphic loci (SAMPL) is one of the microsatellite-based marker systems and a modification of AFLP methodology. The same template is used as in the case of conventional AFLP. Restriction fragments resulting from the digestion of genomic DNA with two endonucleases ligated with adaptors and preamplified using primers designed on the basis of the synthetic adaptor plus the restriction site and carrying one selective base. The selective amplification is achieved using one of the standard AFLP primers with a SAMPL 
primer (Rakoczy-Trojanowska and Bolibok, 2004). The use of a SAMPL primer in combination with an AFLP primer results in the amplification of clear and reproducible fingerprint patterns: SAMPL analysis is particularly suitable for studies where low genetic variation is expected since the primers target the hypervariable microsatellite loci (Witsenboer et al., 1997). This technique, therefore, is theoretically able to detect more polymorphic loci than AFLP markers (Singh et al., 2002).

As mentioned above, only three attempts were made in the past to assess the genetic diversity of walnut cultivars, and all of them were limited to the characterization of the Californian walnut germplasm by using RFLP (Fjellstrom et al., 1994), RAPD (Nicese et al., 1998), and ISSR (Potter et al., 2002) markers. To date, neither a report regarding the extent of genetic diversity of Turkish walnut genotypes that is based on molecular markers nor a characterization of walnut germplasm by AFLPand SAMPL markers were found. Hence, the present study was carried out to assess the genetic diversity and to establish the relationships between different walnut genotypes from different parts of Turkey by using AFLP and SAMPL molecular markers.

\section{Materials and Methods}

Plant material and DNA extraction. After leaves of 21 J. regia genotypes (Table 1) were collected from Nut Research Center of Sutcuimam Univ. in Kahramanmaras, a province of Turkey, they were frozen in liquid nitrogen and stored at $-70{ }^{\circ} \mathrm{C}$ until use. Genomic DNA was extracted from leaf tissue by the CTAB method of Doyle and Doyle (1987) with minor modifications (Kafkas and Perl-Treves, 2001).

AFLPAND SAMPL ReACTIONS. For AFLPand SAMPLanalysis, $250 \mathrm{ng}$ of genomic DNA from each sample was digested with 5 units of EcoRI and 5 units of MseI in a final volume of $25 \mu \mathrm{L}$. The reaction buffer was $10 \mathrm{X}$ RL-buffer (100 mm Tris HAc pH 7.5, 100 mм MgAc, 500 mм KAc, 50 mм DTT). This mixture was incubated for $2 \mathrm{~h}$ at $37^{\circ} \mathrm{C}$. To the double-digested DNA sample,

Table 1. Walnut genotypes and their origins examined for genetic relationship using AFLP and SAMPL markers in this study.

\begin{tabular}{llll}
\hline Code & Genotype & \multicolumn{1}{c}{ Province } & \multicolumn{1}{c}{ Region } \\
\hline 1 & Sebin & Giresun & Black Sea \\
2 & Kaman-1 & Kirsehir & Central Anatolia \\
3 & Kaman-3 & Kirsehir & Central Anatolia \\
4 & Kaman-4 & Kirsehir & Central Anatolia \\
5 & Yalova-1 & Istanbul & Marmara \\
6 & Yalova-3 & Kocaeli & Marmara \\
7 & Yalova-4 & Yalova & Marmara \\
8 & Tokat-1 & Tokat & Black Sea \\
9 & KSU-5 & Kahramanmaras & Southeast Anatolia \\
10 & KSU-11 & Kahramanmaras & Southeast Anatolia \\
11 & Bursa-95 & Bursa & Marmara \\
12 & Van-4 & Bitlis & East Anatolia \\
13 & Kaplan-86 & Yalova & Marmara \\
14 & Sutyemez-1 & Kahramanmaras & Southeast Anatolia \\
15 & Sutyemez-2 & Kahramanmaras & Southeast Anatolia \\
16 & Maras-10 & Kahramanmaras & Southeast Anatolia \\
17 & Maras-18 & Kahramanmaras & Southeast Anatolia \\
18 & Maras-19 & Kahramanmaras & Southeast Anatolia \\
19 & Maras-46 & Kahramanmaras & Southeast Anatolia \\
20 & Maras-12 & Kahramanmaras & Southeast Anatolia \\
21 & Bilecik & Bilecik & Marmara \\
\hline
\end{tabular}

a total volume of $5 \mu \mathrm{L}$ of ligation reaction mixture including 5 pMol of EcoRI adaptor and 50 pmol of $M s e I$ adaptor, 10 mM ATP, 1 unit of T4-DNA ligase, and the same reaction buffer as the above mentioned were added and incubated for $5 \mathrm{~h}$ at $37^{\circ} \mathrm{C}$.

The preselective amplification reaction mixture contained 2.5 $\mu \mathrm{L}$ restricted-ligated DNA as PCR template, $50 \mathrm{ng} \cdot \mu \mathrm{L}^{-1}$ of each of the preselective amplification primers (EcoRI+A and $M s e I+C)$, 2 mM dNTPs, PCR buffer (10 mm Tris-Cl, pH 8.3, $50 \mathrm{~mm} \mathrm{KCl),}$ $2.5 \mathrm{mM} \mathrm{MgCl}_{2}$, and 1 unit of Taq polymerase (Fermentas, Vilnius, Lithuania). The reaction volume was $25 \mu \mathrm{L}$. PCRs were performed as described by Vos et al. (1995) with minor modifications: 20 cycles of $30 \mathrm{~s}$ at $92{ }^{\circ} \mathrm{C}, 30 \mathrm{~s}$ at $60{ }^{\circ} \mathrm{C}$, and $60 \mathrm{~s}$ at $72{ }^{\circ} \mathrm{C}$. After preamplification, the PCR products were diluted 1:20 with $\mathrm{ddH}_{2} \mathrm{O}$. The adaptor sequences, preselective amplification primers and selective primers are listed in Table 2.

The labeling reaction contained $5 \mathrm{ng}$ of EcoRI adaptor binding selective primers, 0.05 units T4 DNA kinase, 1 X T4 DNA kinase buffer, and $0.05 \mu \mathrm{L}$ of $\left[\gamma^{33} \mathrm{P}\right]-\mathrm{ATP}(3000 \mathrm{Ci} / \mathrm{mmol})$ in a final volume of $0.25 \mu \mathrm{L}$ per selective amplification PCR. The labeling was performed for 40 reactions of selective-amplification PCRs at $37^{\circ} \mathrm{C}$ for $1 \mathrm{~h}$ and the enzyme was inactivated by 10 min of incubation at $70{ }^{\circ} \mathrm{C}$.

The selective amplification reaction was conducted in a final volume of $10 \mu \mathrm{L}$ containing $2.5 \mu \mathrm{L}$ of diluted preselective amplification product as a template, $3 \mathrm{ng}$ labeled EcoRI site primer or SAMPL-6 primer, $15 \mathrm{ng}$ Mse I site primer, 2 mM dNTPs, PCR buffer (10 mm Tris-Cl, pH 8.3, $50 \mathrm{~mm} \mathrm{KCl}$ ), $3 \mathrm{~mm} \mathrm{MgCl}_{2}$, and 1 unit of Taq polymerase. The cycling conditions were 11 cycles of denaturation at $94^{\circ} \mathrm{C}$ for $30 \mathrm{~s}$, annealing at $65^{\circ} \mathrm{C}\left(0.7^{\circ} \mathrm{C} / \mathrm{cycle}\right)$ for $30 \mathrm{~s}$, extension at $72^{\circ} \mathrm{C}$ for $60 \mathrm{~s}$, and additional 24 cycles of denaturation, annealing and extension at $94{ }^{\circ} \mathrm{C}$ for $30 \mathrm{~s}, 56{ }^{\circ} \mathrm{C}$ for $30 \mathrm{~s}$, and $72{ }^{\circ} \mathrm{C}$ for $60 \mathrm{~s}$, respectively. Ten microliters of the AFLP selective amplification product was mixed with $10 \mu \mathrm{L}$ of loading buffer (98\% formamide, $10 \mathrm{~mm}$ EDTA, $0.25 \%$ each of bromophenol blue and xylene cyanol FF), then denatured at 94 ${ }^{\circ} \mathrm{C}$ for $5 \mathrm{~min}$ and placed immediately on ice. Electrophoresis was performed on an EC160 standard sequencing unit (Thermo Elec-

Table 2. Sequences of oligonucleotide adaptors and primers used in the characterization of 21 walnut genotypes by the AFLP and SAMPL markers.

\begin{tabular}{|c|c|c|}
\hline Adaptor/primer & Code & Sequence \\
\hline Adaptors & & \\
\hline EcoRI adaptors & & $\begin{array}{l}5^{\prime}-\mathrm{CTC} \text { GTA GAC TGC GTA CC-3' } \\
3^{\prime}-\mathrm{CAT} \text { CTG ACG CAT GGT TAA-5' }\end{array}$ \\
\hline MseI adaptors & & $\begin{array}{l}5^{\prime}-\mathrm{GAC} \text { GAT GAG TCC TGA G-3' } \\
3^{\prime}-\mathrm{TA} \text { CTC AGG ACT CAT-5' }\end{array}$ \\
\hline
\end{tabular}

Preselective amplification primers

$E c o$ RI primer + A $\quad \mathrm{E}_{\mathrm{A}} \quad 5^{\prime}$-GACTGCGTACCAATTC+A-3' Mse I primer + C $\quad \mathrm{M}_{\mathrm{C}} \quad$ 5'-GATGAGTCCTGAGTAA+C-3' Selective amplification primers
EcoRI + 3-ACG
$\mathrm{E}_{\mathrm{ACG}}$
5'-GACTGCGTACCAATTC+ACG-3'
MseI + 3-AAG
$\mathrm{M}_{\mathrm{AAG}}$ 5'-GATGAGTCCTGAGTAA+AAG-3'
$M s e \mathrm{I}+3-\mathrm{ACA}$
$\mathrm{M}_{\mathrm{ACA}}$ 5'-GATGAGTCCTGAGTAA+ACA-3'
$\mathrm{Mse} \mathrm{I}+3-\mathrm{AGA}$
$\mathrm{M}_{\mathrm{AGA}}$
5'-GATGAGTCCTGAGTAA+AGA-3'
$M s e I+3-A G C$
$\mathrm{M}_{\mathrm{AGC}}$ 5'-GATGAGTCCTGAGTAA+AGC-3'
$\mathrm{Mse} \mathrm{I}+3$-AGG
$\mathrm{M}_{\mathrm{AGG}}$
5'-GATGAGTCCTGAGTAA+AGG-3'
$M s e \mathrm{I}+3-\mathrm{AGT}$
$\mathrm{M}_{\mathrm{AGT}}$
5'-GATGAGTCCTGAGTAA+AGT-3'
Mse I + 3-ATA
$\mathrm{M}_{\mathrm{ATA}}$
5'-GATGAGTCCTGAGTAA+ATA-3'

SAMPL primer

SAMPL-6

5'-ACACACACACACACATATAA-3' 
tron Corp., Milfort, Mass.). Two PCR reactions were performed for each primer combination.

About $3 \mu \mathrm{L}$ of mixture was loaded onto a $4.5 \%(w / v)$ polyacrylamide denaturing gel with $0.5 \mathrm{X}$ TBE buffer after a prerun electrophoresis at $60 \mathrm{~V}$ for $30 \mathrm{~min}$, and then were run at $60 \mathrm{~V}$ until the loading dye reached to the bottom of the gel. The gels were dried at $80{ }^{\circ} \mathrm{C}$ for $3 \mathrm{~h}$. Hyperfilm-Multi Purpose (Amersham Biosciences, Buckinghamshire, England) was exposed to the gels for $2 \mathrm{~d}$.

BAND SCORING AND DATA ANALYSIS. The AFLP and SAMPL bands were scored manually as present (1) or absent (0). Only the clearest and strongest bands were scored and used for the analysis. The ability of the most informative primer pairs to differentiate between the genotypes was assessed by calculating their resolving power (Rp) according to Prevost and Wilkinson (1999) using $\mathrm{Rp}=\sum \mathrm{Ib}$, where $\mathrm{Ib}=1-[2 \mathrm{x}(0.5-\mathrm{p})]$ and $\mathrm{p}$ is the proportion of the 21 genotypes containing the I band.

Parsimony analysis was performed using phylogenetic analysis using parsimony program (PAUP 4.0b; Swofford, 1998) with different Heuristic search-options. A consensus tree was constructed from 500 bootstrap replicates of the same data. Genetic distances between all pair-wise combinations of genotypes were calculated by the same program. The distance values were based on the proportion of different bands between all the possible pairs of genotypes. The same binary data was also used to construct a neighbor-joining tree based on the Nei and Li (1979) distance matrix using the same package software.

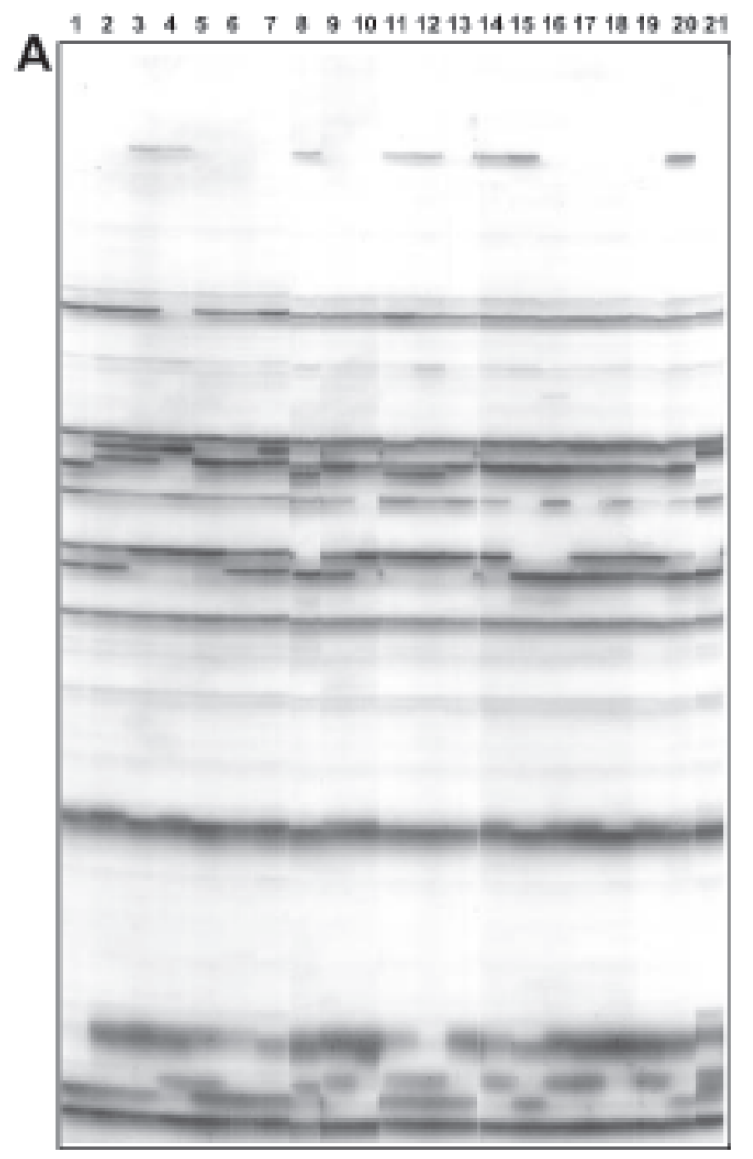

\section{Results and Discussion}

LEVELS OF POLYMORPHISM AND RESOLVING POWERS OF THE PRIMER PAIRS. Six AFLP and two SAMPL primer combinations were used in the molecular characterization of 21 walnut genotypes originated from different regions of Turkey. Fingerprinting patterns of walnut genotypes using $\mathrm{E}_{\mathrm{ACG}} / \mathrm{M}_{\mathrm{AGT}}$ primer combination in AFLP and SAMPL-6/M $\mathrm{M}_{\mathrm{AGT}}$ primer pair in SAMPL are shown in Fig. 1A and 1B, respectively. A total of 230 bands were obtained and 116 of them (50.4\%) were polymorphic with an average of 28.8 total bands and 14.5 polymorphic markers per primer pair (Table 3). The six AFLP primer sets produced in total 179 bands and $49.9 \%$ of them were polymorphic with an average of 29.8 bands per primer pair. In SAMPL analysis, the two primer combinations amplified 51 fragments and $50.9 \%$ of them pointed out that there is polymorphism among walnut genotypes. The average number of total and polymorphic bands per primer in SAMPL was slightly lower than AFLP, whereas the percentage of polymorphisms per primer was slightly higher in SAMPL than in AFLP. The maximum number of bands was 36 for primer combination $\mathrm{E}_{\mathrm{ACG}} / \mathrm{M}_{\mathrm{ATA}}$, whereas the lowest number of bands (23) was obtained with primer pair $\mathrm{E}_{\mathrm{ACG}} / \mathrm{M}_{\mathrm{AGC}}$ (Table 3). The highest level of polymorphism was found with primer pairs $\mathrm{E}_{\mathrm{ACG}} / \mathrm{M}_{\mathrm{AGA}}(55.3 \%)$, SAMPL-6/M $\mathrm{M}_{\mathrm{AGG}}(53.8 \%)$, and $\mathrm{E}_{\mathrm{ACG}} / \mathrm{M}_{\mathrm{ACA}}$ $(53.6 \%)$, whereas the lowest one $(43.5 \%)$ was generated with $\mathrm{E}_{\mathrm{ACG}} / \mathrm{M}_{\mathrm{AGC}}$ primer combination. The low number of AFLP and SAMPL bands that were detected in this study was compared to

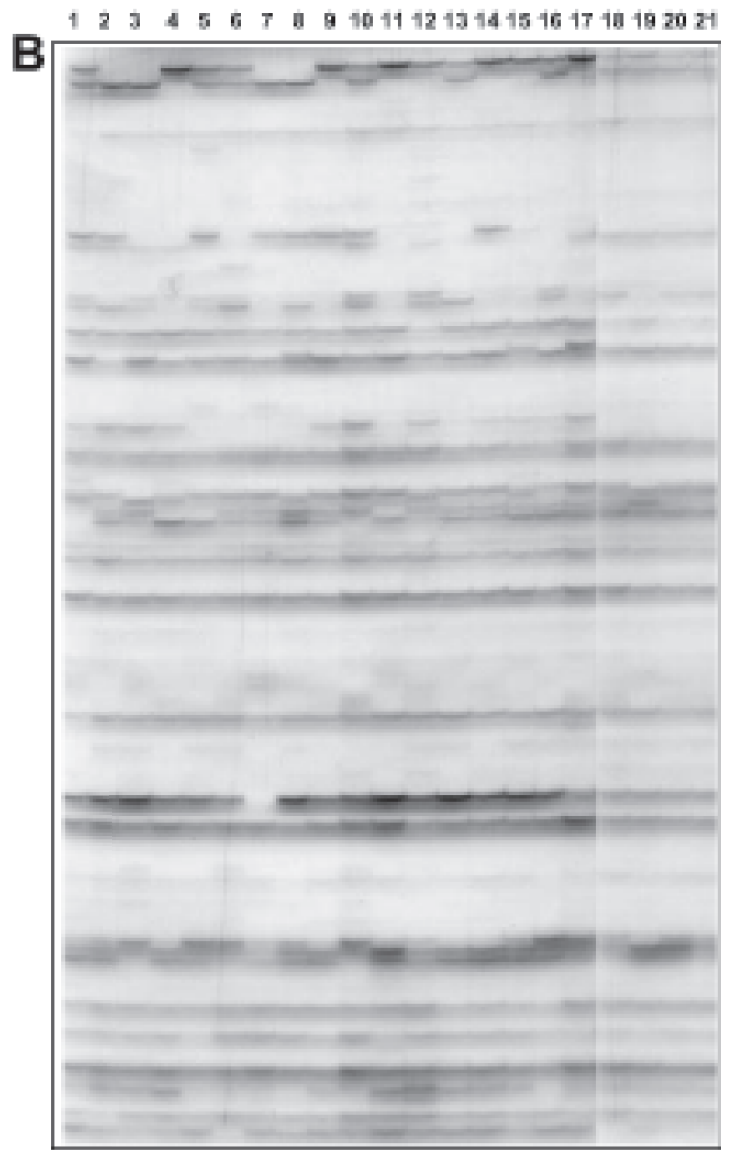

Fig. 1. Fingerprinting of 21 walnut genotypes (A) by AFLP using $E_{A A C} \times M_{A G T}$ primer combination and (B) by SAMPL using SAMPL- $6 \times M_{A G T}$ primer pair. Lanes are: 1) 'Sebin', 2) 'Kaman-1',3) 'Kaman-3', 4) 'Kaman-4', 5) 'Yalova-1', 6) 'Yalova-3', 7) 'Yalova-4', 8) 'Tokat-1', 9) 'KSU-5', 10) 'KSU-11', 11) 'Bursa-95', 12) 'Van-4', 13) 'Kaplan-86', 14) 'Sutyemez-1', 15) 'Sutyemez-2', 16) 'Maras-10', 17) 'Maras-18', 18) 'Maras-19', 19) 'Maras-46', 20) 'Maras-12', and 21) 'Bilecik'. 
Table 3. Number of total and polymorphic bands, percentage of polymorphism, and resolving powers of primer pairs detected in the DNA fingerprinting of 21 walnut genotypes with AFLP and SAMPL markers.

\begin{tabular}{lcccc}
\hline $\begin{array}{l}\text { Primer } \\
\text { combinations }\end{array}$ & $\begin{array}{c}\text { Total } \\
\text { bands } \\
\text { (no.) }\end{array}$ & $\begin{array}{c}\text { Polymorphic } \\
\text { bands } \\
\text { (no.) }\end{array}$ & $\begin{array}{c}\text { Poly- } \\
\text { morphism } \\
(\%)\end{array}$ & $\begin{array}{c}\text { Resolving } \\
\text { power } \\
(\mathrm{Rp})\end{array}$ \\
\hline $\mathrm{E}_{\mathrm{ACG}} / \mathrm{M}_{\mathrm{AAG}}$ & 34 & 17 & 50.0 & 15.3 \\
$\mathrm{E}_{\mathrm{ACG}} / \mathrm{M}_{\mathrm{ACA}}$ & 28 & 15 & 53.6 & 18.9 \\
$\mathrm{E}_{\mathrm{ACG}} / \mathrm{M}_{\mathrm{AGA}}$ & 29 & 16 & 55.3 & 17.5 \\
$\mathrm{E}_{\mathrm{ACG}} / \mathrm{M}_{\mathrm{AGC}}$ & 23 & 10 & 43.5 & 10.3 \\
$\mathrm{E}_{\mathrm{ACG}} / \mathrm{M}_{\mathrm{AGT}}$ & 29 & 15 & 51.7 & 18.1 \\
$\mathrm{E}_{\mathrm{ACG}} / \mathrm{M}_{\mathrm{ATA}}$ & 36 & 17 & 47.2 & 17.0 \\
Subtotal/mean & $179 / 29.8$ & $89 / 14.8$ & 49.9 & $97.1 / 16.2$ \\
$\mathrm{SAMPL6} / \mathrm{M}_{\mathrm{AGG}}$ & 26 & 14 & 53.8 & 13.7 \\
$\mathrm{SAMPL6} / \mathrm{M}_{\mathrm{AGT}}$ & 25 & 12 & 48.0 & 16.1 \\
Subtotal/mean & $51 / 25.5$ & $26 / 13.0$ & 50.9 & $29.8 / 14.9$ \\
Total/mean & $230 / 28.8$ & $116 / 14.5$ & 50.4 & $126.9 / 15.9$ \\
\hline
\end{tabular}

previous reports in different plant species (Paglia and Morgante, 1998; Roy et al., 2002; Singh et al., 2002; Tseng et al., 2002; Witsenboer et al., 1997). The findings can be explained by the use of selective primers with three nucleotides and by the scoring of only clear and strong bands in the gel. One of the problems emerging while utilizing multiplex fingerprinting techniques such as AFLP and SAMPL is the high complexity of amplification profiles. To deal with this problem, an option is to increase the number of selective nucleotides on the primers (Hayden and Sharp, 2001). In this study, we followed this approach both for AFLP and SAMPL analysis, therefore, lower numbers of bands were amplified.

By using 18 RAPD primers, Nicese et al. (1998) observed 23 polymorphic fragments that correspond to $\approx 25 \%$ polymorphism, with an average of 1.3 loci per primer. In our study, using six AFLP and two SAMPL primer-pairs, we observed 230 fragments with an average of 14.5 polymorphic loci per primer pair. This indicates that AFLP and SAMPL primer pairs on average detected 11 times more polymorphisms per primer pair than RAPD primers.

Potter et al. (2002) recorded 31 polymorphic bands out of a total of 54 ISSR fragments scored, with an average of 3.9 polymorphic bands per primer. In this study, eight AFLP and SAMPL primer pairs detected, on average, 3.7 times more polymorphisms per primer pair, even though the proportion of polymorphic bands per total number of bands detected was lower for AFLPs and SAMPLs in walnut.

The walnut genotypes characterized in these studies were from different countries and continents. In the RFLP study (Fjellstrom, et al., 1994), walnut genotypes from 12 different origins all over the world were assessed; in the RAPD analysis (Nicese et al., 1998), the authors fingerprinted 19 genotypes from California, France, Afghanistan, and China; and in the ISSR experiment (Potter et al., 2002), 47 genotypes originated from different countries in America, Europe and Asia continents were characterized. With regard to these, in this study, 21 walnut genotypes, all from Turkey, were analyzed. Therefore, the effectiveness of different methodologies used in these walnut genetic diversity studies can be compared. These results also demonstrate the usefulness of AFLP and SAMPL techniques in germplasm diversity studies for walnut when compared to PCR-based techniques such as RAPDs and ISSRs.

The resolving power (Rp) of the primer combinations (Table 3) ranged between $10.1\left(\mathrm{E}_{\mathrm{ACG}} / \mathrm{M}_{\mathrm{AGC}}\right)$ and $18.9\left(\mathrm{E}_{\mathrm{ACG}} / \mathrm{M}_{\mathrm{ACA}}\right)$.
According to the Rp values of all primer pairs, AFLP primer combinations seemed to discriminate 21 walnut genotypes better than the SAMPL primer pairs. However, the SAMPL technique was more effective than AFLP in the separation of very close genotypes. This is apparent in the closest genotype pairs of 'Maras-12' and 'Sutyemez-2' that are different by only 12 bands. Five of them were produced by two SAMPL primer sets and seven from six AFLP combinations. Similar results were obtained from another similar genotype pair of 'KSU-5' and 'Sutyemez1 ', which differed only in 10 fragments. The SAMPL technique was superior to AFLP in resolving differences between closely related genotypes as in previous studies which were performed with different plant species (Porceddu et al., 2002; Singh et al., 2002; Tosti and Negri, 2002).

In cultivar identification, AFLP and SAMPL techniques are more reliable in walnut than other methods and especially RAPD which has reproducibility problems. In plants, the efficiency of different types of markers was compared in many studies and AFLP was found to have higher reproducible bands and polymorphism when compared to the RAPDs and ISSRs. Nonetheless, the high costs and the need of skilled technicians are mentioned as the drawbacks of AFLP analysis (Patzak, 2001).

Our results suggest the existence of high genetic variation in walnut at the intra-specific level as revealed by AFLP and SAMPL analysis. Previous studies in walnut using ISSR, RAPD, and RFLP markers also reported sufficient polymorphism within J. regia. This result may be explained by the high heterogeneity and outcrossing rate of this species, and consequence of its monoecious and dichogamous reproduction habit.

GENETIC RELATEDNESS AMONG WALNUT GENOTYPE. The data in this study were analyzed using two different approaches. The parsimony method, in which only phylogenetically informative characters are used to construct the shortest tree by stepwise addition of taxa and characters, yielded four shortest trees with 368 steps long: Fig. 2 depicts one of them as unrooted. The data were also analyzed with a distance matrix method, and the resulting neighbor joining tree was identical to the parsimony tree (data not shown).

Figure 2 shows that the 21 walnut genotypes are clearly separated from each other based on AFLP and SAMPL fingerprintings. Abranch of 6 steps separated the walnut genotypes into two groups. The first group included nine genotypes from Kahramanmaras province. This group also collected 'Kaman-3', 'Kaman-4', 'Van4', and 'Tokat-1' genotypes, although they were separated from the Kahramanmaras ones by a branch of four steps. The second group gathered mainly the genotypes originated from the Marmara region. 'Sebin' and 'Kaman-1' genotypes clustered in the second group as well. The pair-wise genetic distance values based on 230 AFLP and SAMPL markers ranged from 0.013 to 0.232 (genetic distance units). The genotypes 'Maras-18' and 'Maras-46', 'KSU5' and 'Sutyemez-1', 'Maras-12' and 'Sutyemez-2', 'Kaman-3' and 'Kaman-4', and 'KSU-11' and 'Maras-10' were the closest pairs. According to the average distances between a genotype and all the other genotypes, 'Bilecik' (0.182 unit), 'Yalova 3' (0.182 unit), 'Van-4' (0.178 unit), and 'Yalova-4' (0.176 unit) appeared to be the most diverged genotypes, whereas 'Maras-12' had the lowest average genetic distance.

Efficient conservation and utilization of plant genetic resources, and successful breeding programs rely on a deep knowledge of the amount and distribution of the genetic diversity present in the germplasm, and on the genetic divergence and relatedness existing among breeding materials. Besides providing a much needed 


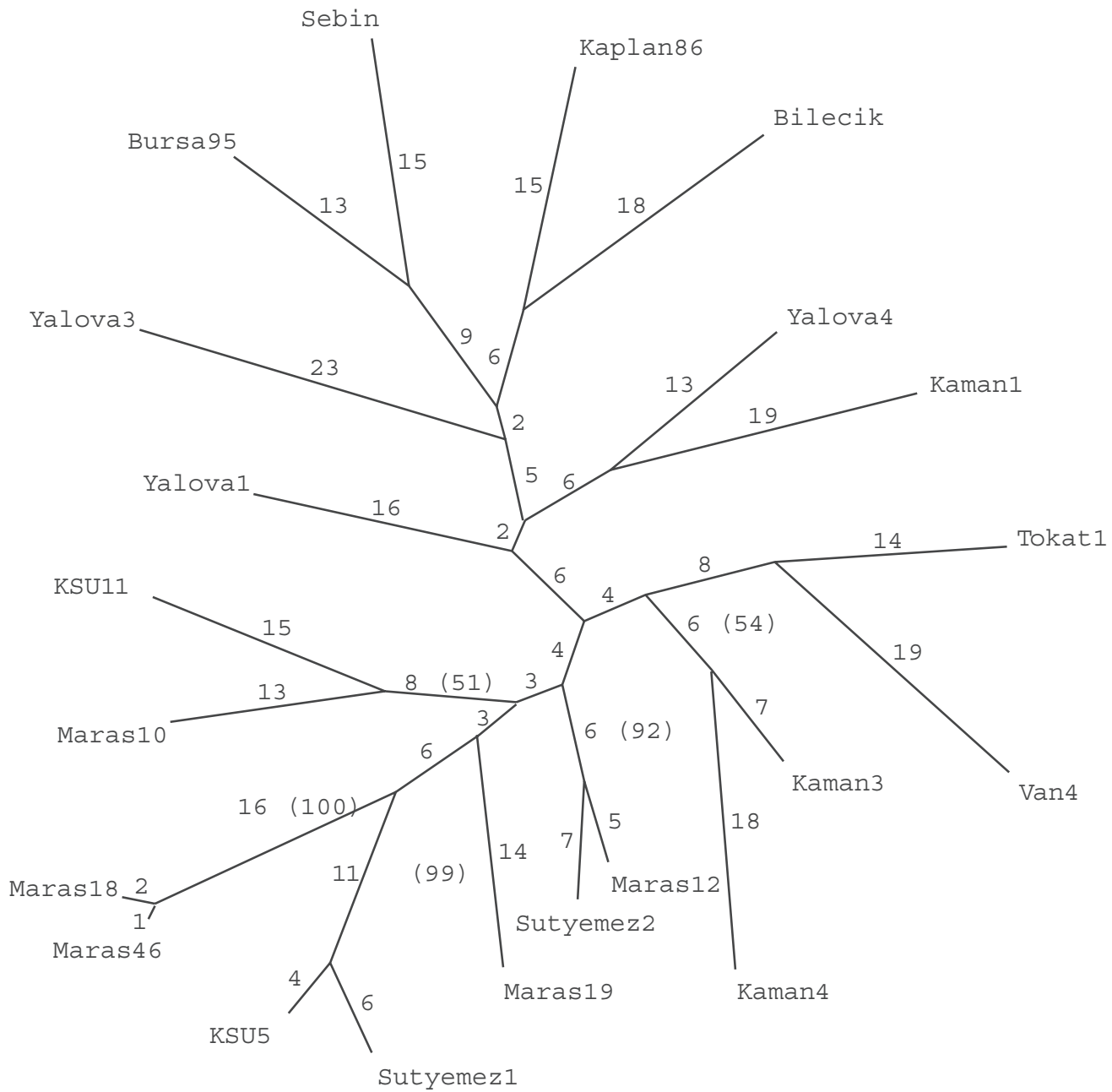

Fig. 2. Parsimony analysis of AFLP and SAMPL fingerprinting data from 21 walnut genotypes. The data-base included 179 AFLP and 51 SAMPL bands. A heuristic search was conducted by the phylogenetic analysis using parsimony (PAUP) software using tree bisection reconnection (TBR) swapping resulting in four trees of 368 steps. One (consistency index $=0.310$ ) of the trees is depicted. Numbers indicate the length (number of steps) of each branch. Percentage values of 500 bootstrap replicates of the same data are shown in paranthesis.

genetic background, such studies also facilitate the planning of new breeding approaches for cultivar improvement.

In conclusion, the results in this study are significant for further walnut breeding programs and development of the walnut crop in Turkey, helping the growers in the identification of walnut genotypes, and assisting walnut breeders in parent selection. Furthermore, the findings of this study will facilitate further molecular studies in walnut by means of AFLP and SAMPL techniques.

\section{Literature Cited}

Akca, Y. 2003. Türkiye ceviz yetistiriciligine genel bakis. 30 Sept 2004. http://www. ceviz.gen.tr/yazi1. htm.

Aleta, N., C. Olarte, M.J. Truco, and P. Arus. 1990. Identification of walnut cultivars by isozyme analysis. Acta Hort. 284:91-96.

Aleta, N., M. Rovira, A. Ninot, and P. Arus. 1993. Inheritance of four isozymes in walnut. Acta Hort. 311:62-67.

Aly, M.A.M., R.G. Fjellstrom, G.H. McGranahan, and D.E. Parfitt. 1992. Origin of walnut somatic embryos determined by RFLP and isozyme analysis. HortScience 27:61-63.

Arulsekar, S., G.H. McGranahan, and D.E. Parfitt. 1986. Inheritance of phosphoglucomutase and esterase isoyzmes in Persian walnut. J. Hered. 77:220-221.
Arulsekar, S., D.E. Parfitt, and G.H. McGranahan. 1985. Isozyme gene markers in Juglans species inheritance of GPI and AAT in J. regia and J. hindsii. J. Hered. 76:103-106.

Celebioglu, G. 1985. Ceviz yetistiriciligi. Kocaoluk Yayınevi, Bursa, Turkey.

Doyle, J.J. and J.L. Doyle, 1987. A rapid isolation procedure for small quantities of fresh leaf tissue. Phytochem. Bul. 19:11-15.

FAO, 2003. Agricultural production, crops primary. 30 Sept. 2004. $<$ http://apps.fao.org/faostat>

Fjellstrom, R.G., D.E. Parfitt, and G.H. McGranahan. 1994. Genetic relationships and characterization of Persian walnut ( $J$. regia L.) cultivars using restriction fragment length polymorphisms (RFLPs). J. Amer. Soc. Hort. Sci. 119:833-839.

Fjellstrom, R.G. and D.E. Parfitt.1985 1994a. Walnut (Juglans spp.) genetic diversity determined by restriction fragment length polymorphisms. Genome 37:690-700.

Fjellstrom, R.G. and D.E. Parfitt. 1994b. RFLP inheritance and linkage in walnut. Theor. Appl. Genet. 89:665-670.

Fjellstrom, R.G. and D.E. Parfitt. 1995. Phylogenetic analysis and evolution of the genus Juglans (Juglandaceae) as determined from nuclear genome RFLPs. Plant Syst. Evol. 197:19-32.

Fornari, B., M.E. Malvolti, D. Taurchini, and S. Fineschi. 2001. Isozyme and organellar DNA analysis of genetic diversity in natural/naturalised European and Asiatic walnut (Juglans regia L.) populations. Acta Hort. 544:167-178. 
Germain, E., I. Hanguier, and R. Monet. 1993. Identification of eight Juglans spp. and their interspecific hybrids by isoenzymatic electrophoresis. Acta Hort. 311:73-85.

Hayden, M.J. and P.J. Sharp. 2001. Targeted development of informative microsatellite (SSR) markers. Nucl. Acids Res. 29:e44.

Kafkas, S. and R. Perl-Treves. 2001. Morphological and molecularphylogeny of Pistacia species in Turkey. Theor. Appl. Genet. 102:908-915.

Louskas, M., K. Pontikis, I. Vergini, and K. Papalexandras. 1984. Identification of walnut and filbert cultivars by isoenzymatic electrophoresis. Acta Hort. 311:86-91.

Malvolti, M.E., M. Paciucci, F. Cannata, and S. Fineschi. 1993. Genetic variation in Italian populations of Juglans regia L. Acta Hort. 311:86-94.

Malvolti, M.E., M. Spada, I. Beritognolo, and F. Cannata. 1997. Differentiantion of walnut hybrids (Juglans nigra L. $x$ Juglans regia L.) through RAPD markers. Acta Hort. 462:43-52.

Malvolti, M.E., B. Fornari, E. Maccaglia, and F. Cannata. 2001. Genetic linkage mapping in an intraspesific cross of walnut (Juglans regia L.) using molecular markers. Acta Hort. 544:179-185.

Manning, W.E. 1978. The classification within the Juglandaceae. Ann. Mo. Bot. Gard. 65:1058-1087.

Nei, M. and W. Li. 1979. Mathematical model for study the genetic variation in terms of restriction endonucleases. Proc. Natl. Acad. Sci. USA 74:5267-5273.

Nicese, F.P., J.I. Hormaza, and G.H. McGranahan. 1998. Molecular characterization and genetic relatedness among walnut (Juglans regia L.) genotypes based on RAPD markers. Euphytica 101:199-206.

Olez, H. 1971. Marmara bolgesi cevizlerinin seleksiyon yoluyla islahi uzerinde arastirmalar ve ceviz agaclarinda verim potansiyelinin tespiti icin gelistirilmis bir metod. Yalova Bahce Kulturleri Arastirma ve Egitim Merkezi Dergisi 4:7-30.

Paglia, G. and M. Morgante. 1998. PCR-based multiplex DNA fingerprinting techniques for the analysis of conifer genomes. Mol. Breed. 4:173-177.

Patzak, J. 2001. Comparison of RAPD, STS, ISSR and AFLP molecular methods used for assessment of genetic diversity in hop (Humulus lupulus L.). Euphytica 121:9-18.

Porceddu, A., E. Albertini, G. Barcaccia, E. Falistocco, and M. Falcinelli. 2002. Linkage mapping in apomictic and sexual Kentucky bluegrass (Poa pratensis L.) genotypes using a two way pseudo-testcross strategy based on AFLP and SAMPL markers. Theor. Appl. Genet. 104:273-280.

Potter, D., F. Gao, G. Aiello, C. Leslie, and G.H. McGranahan, 2002. Intersimple sequence repeat markers for fingerprinting and determining genetic relationships of walnut (Juglans regia) cultivars. J. Amer. Soc. Hort. Sci. 127:75-81.
Powell, W., M. Morgante, C. Andre, M. Hanafey, J. Vogel, S. Tingey, and A. Rafalski. 1996. The comparison of RFLP, RAPD, AFLP and SSR (microsatellite) markers for germplasm analysis. Mol. Breed. 2:225-238.

Prevost A. and M.J. Wilkinson. 1999. A new system of comparing PCR primers applied to ISSR fingerprinting of potato accessions. Theor. Appl. Genet. 98:107-112.

Rakoczy-Trojanowska, M. and H. Bolibok. 2004. Characteristics and a comparison of three classes of microsatellite-based markers and their application in plants. Cell. Mol. Biol. Lett. 9:221-238.

Roy, J.K., H.S. Balyan, M. Prassad, and P.K. Gupta. 2002. Use of SAMPL for a study of DNA polymorphism, genetic diversity and gene tagging in bread wheat. Theor. Appl. Genet. 104:465-472.

Sen, S.M. 1986. Ceviz yetistiriciligi. Eser Matbaası, Samsun, Turkey. Singh, A., A. Chaudhury, P.S. Srivastava, and M. Lakshmikumaran. 2002. Comparison of AFLP and SAMPL markers for assessment of intra-population genetic variation in Azadirachta indica A. Juss. Plant Sci. 162:17-25.

Solar, A., J. Smole, and F. Stampar. 1993. Identification of walnut cultivars by pollen isozymes. Acta Hort. 311:95-100.

Swofford, D.L. 1998. PAUP. Phylogenetic analysis using parsimony (and other methods). version 4. Sinauer Assoc., Sunderland, Mass.

Tosti, N. and V. Negri. 2002. Efficiency of three PCR-based markers in assessing genetic variation among cowpea (Vignia unguiculata subsp. unguiculata) landraces. Genome 45:268-275.

Tseng, Y.T, H.F. Lo, and S.Y. Hwang. 2002. Genotyping and assessment of genetic relationships in elite polycross breeding cultivars of sweet potato in Taiwan based on SAMPL polymorphisms. Bot. Bul. Acad. Sinica 43:99-105.

Vos, P., L. Hogers, M. Bleeker, T. Van De Lee, M. Hornes, A. Frijters, J. Pot, J. Peleman, M. Kuiper, and M. Zabeau, 1995. AFLP: A new technique for DNA fingerprinting. Nucl. Acids Res. 23:4407-4414.

Wenheng, C.S.Y. 1984. Taxonomic studies of ten species of the genus Juglans based on isozyme zymograms. Acta Hort. Sinica 14:90-96.

Witsenboer, H., J. Vogel, and R.W. Michelmore. 1997. Identification, genetic localization and allelic diversity of selectively amplified microsatellite polymorphic loci in lettuce and wild relatives (Lactuca spp.). Genome 40:923-936.

Woeste, K., G.H. McGranahan, and R. Bernatzky. 1996a. Randomly amplified polymorphic DNA loci from a walnut backcross [(Juglans hindsii $x$ Juglans regia) x Juglans regia] . J. Amer. Soc. Hort. Sci. 121:358-361.

Woeste, K., G.H. McGranahan, and R. Bernatzky. 1996b. The identification and characterization of a genetic marker linked to hyper-sensivity to the cherry leafroll virus in walnut. Mol. Breed. 2:261-266. 